UDC 678.6:678.7

\author{
K.E. Varlan ${ }^{a}$, D.O. Chervakov ${ }^{b}$, O.S. Sverdlikovska ${ }^{b}$, E.C. Zahinayko ${ }^{c}$, I.M. Severenchuk ${ }^{a}$
}

\title{
MODIFIED PHENOLIC RESINS AND THEIR COMPATIBILITY WITH THE COMPONENTS OF EPOXY-PHENOLIC PROTECTIVE COATINGS
}

\author{
a Oles Honchar Dnipro National University, Dnipro, Ukraine \\ ${ }^{b}$ Ukrainian State University of Chemical Technology, Dnipro, Ukraine \\ c Dnipropetrovsk Forensic Research Center of the Ministry of Internal Affairs of Ukraine, Dnipro, \\ Ukraine
}

\begin{abstract}
Condensation products of resorcinol mono-esterified by maleic anhydride, diphenylpropane with formaldehyde, products of maleinization and glycidation by butylphenol formaldehyde resins were synthesized. The obtained products can be used in film-forming systems. The methods of the synthesis were developed; the characteristics of the synthesized phenolic resins and the results of the IR-spectral analysis of intermediates and end products were given. Formulation of the model film-forming systems based on the synthesized resins was performed by predicting their thermodynamic compatibility with other components (oils and solvents) using Hildebrand parameters, the solubility being calculated by the Askadsky method. Experimental verification showed that the obtained results complied with the predictions on the compatibility of the synthesized resins with tung and epoxidized soy oils and solvents. The synthesized compounds can be considered promising components for protective coatings in combination with drying and epoxidized oils.
\end{abstract}

Keywords: maleic anhydride, resorcinol, diphenylolpropane, modified phenolic resin, solubility parameter, protective coating.

DOI: $10.32434 / 0321-4095-2020-128-1-10-17$

\section{Introduction}

Phenolic resins have been used in industrialscale production for more than 100 years, though, they retain their relevance [1]; moreover, their demand shows a growing trend. Materials and goods based on phenolic resins are widely used in many fields due to the variety of their operational characteristics. For instance, phenolic resins are used as binders and film-forming components in the compositions for protective coatings [2]. It is known that paint compositions (paints and varnishes) for multi-functional protective coatings have been developed based on modified phenolic resins $[3,4]$. For example, phenolic resins based on alkylphenol are used in tin coatings [5]. Phenolic resins modified by epoxy resins are offered for enamels with improved physical-mechanical and thermal-physical properties [6]. Film-forming epoxy-phenolic systems containing phenolic resins, which are based on resorcinol, provide coatings with good adhesion to the metal and glass surfaces [7]. Coatings based on butanolized condensation products of diphenylpropane (BPA) and formaldehyde [8-10] are characterized by unique physical-mechanical and protective properties.

According to analysis of available literature and patent data, the modified phenolic resins are important in the development of new epoxy-phenolic coatings. Modified phenolic resins based on n-tertbuthylphenol (BP), resorcinol (R) and diphenylpropane have been synthesized. Their application as the components of epoxy-phenolic film-forming systems has been investigated to expand the range of phenolic derivatives applicable for epoxyphenolic compositions, which are used in protective coatings with improved properties. There is also a feasibility to gain paint compositions, which combine performances of epoxy-phenolic and polyesters filmforming systems. There are two following ways to reach this goal: mono esterification of bis phenols by resorcinol and diphenylpropane by maleic anhydride (MA) with the next condensation of monomaleinates with formaldehyde and modification of p-tert-buthylphenolformaldehyde resin (BR) through the esterification of maleic anhydride or

(C) K.E. Varlan, D.O. Chervakov, O.S. Sverdlikovska, E.C. Zahinayko, I.M. Severenchuk, 2020

K.E. Varlan, D.O. Chervakov, O.S. Sverdlikovska, E.C. Zahinayko, I.M. Severenchuk 
glycidation by epichlorohydrin $(\mathrm{ECH})$.

\section{Experimental}

Synthesis of resorcinol and diphenylpropane adduct with maleic anhydride

Resorcinol (11.0 g, $0.1 \mathrm{~mol})$, or diphenylpropane $(11.4 \mathrm{~g}, 0.05 \mathrm{~mol})$ and ethyl acetate were put into tree neck flask $(0.1 \mathrm{~L})$ equipped with a stirring rod, a thermometer and a backflow condenser. The mixture was stirred at $50^{\circ} \mathrm{C}$ until the solution creation. Then, $9.81 \mathrm{~g}(0.1 \mathrm{~mol})$ of maleic anhydride was added. After the solution creation, the temperature was increased up to $70^{\circ} \mathrm{C}$. The reaction mass was stirred for 3 hours. After a backflow condenser changed to direct, solvent was distilled at the atmosphere pressure, followed by water-jet pump vacuum up to $95^{\circ} \mathrm{C}$. Remained yellow crystallized substances was solved in water and organic solvents (alcohol, acetone and toluene). Both melting temperature $\left(\mathrm{T}_{\mathrm{m}}\right)$ and mole-equivalent masses (ME) were defined by potentiometry of carboxyl group (Table 1). A further transformations of adducts were carried out in the same reactor without preliminary withdrawals.

Table 1

The characteristics of adducts of bisphenols with maleic anhydride

\begin{tabular}{c|c|c|c|c}
\hline $\begin{array}{c}\text { Short } \\
\text { name }\end{array}$ & Bisphenol & $\begin{array}{c}\text { Ethyl acetate, } \\
\mathrm{mL}\end{array}$ & $\begin{array}{c}\mathrm{M}_{\mathrm{E}}, \\
\mathrm{g} /(\text { mol-eq })\end{array}$ & $\mathrm{T}_{\mathrm{m}},{ }^{0} \mathrm{C}$ \\
\hline PM & Resorcinol & 25 & 213.7 & $130-131$ \\
\hline $\mathrm{DM}$ & BPA & 35 & 335.3 & $162-163$ \\
\hline
\end{tabular}

Synthesis of phenolic resin based on resorcinol adduct and maleic anhydride (PPR)

Water, 39\% aqueous solution of formaldehyde and, if needed, oxalic acid (OA) were added to PM adduct. Then, the mixture was stirred at ambient temperature until the solution creation. The reaction mass was stirred at $75^{\circ} \mathrm{C}$ for 3 hours and at $85^{\circ} \mathrm{C}$ for 1 hour. After obtaining a viscous and homogeneous mass, butyl alcohol was added whereas water was extracted by azeotropic distillation with Dean-Stark trap. Then, butyl alcohol was distilled over the vacuum of a waterjet pump up to $110^{\circ} \mathrm{C}$. The final product was retinoid transparent red substance, which is readily soluble in acetone, toluene and alcohol, however, insoluble in water. The ingredients, which were not mentioned above, are shown in Table 2.

Synthesis of phenolic resin based on adduct of diphenylpropane with maleic anhydride (DPR)

The synthesis is similar to the above-stated until the end of the condensation of the adduct with formaldehyde. At the end of the reaction, a mass was separated into tar-water and organic product, which hardened at room temperature. Water part was extracted; butyl alcohol was added to the reactor where the mass was stirred at $45-50^{\circ} \mathrm{C}$ for 2 hours. Butyl alcohol was distilled under vacuum at $95^{\circ} \mathrm{C}$. The final product was retinoid transparent light brown substance, which is water-insoluble, readily soluble in acetone and poorly soluble in toluene and alcohol. The ingredients, which were not mentioned above, are presented in Table 2.

Synthesis of comparative samples of phenolic resins based on resorcinol adducts and diphenylpropane with maleic anhydride (PPR' and DPR', respectively)

These products were synthesized by similar methods. The only difference was the use of toluene instead of butyl alcohol (in both cases).

Table 2

Synthesis conditions and modified phenolic resins characteristics

\begin{tabular}{c|c|c|c|c|c|c}
\hline Short name & Adduct, mol & Formaldehyde, mol & $\mathrm{OA}, \mathrm{mol}$ & $\mathrm{H}_{2} \mathrm{O}, \mathrm{mL}$ & Butyl alcohol, $\mathrm{mL}$ & $\mathrm{T}_{\mathrm{cr}},{ }^{0} \mathrm{C}$ \\
\hline PPR-1 & 0.10 & 0.085 & 0.01 & 22.0 & 30 & 54 \\
\hline PPR-2 & 0.10 & 0.085 & - & 22.0 & 30 & 71 \\
\hline PPR-3 & 0.10 & 0.090 & 0.01 & 21.5 & 30 & 93 \\
\hline PPR-4 & 0.10 & 0.100 & - & 20.5 & 30 & 99 \\
\hline PPR-5 & 0.10 & 0.125 & - & 18.0 & 30 & 103 \\
\hline PPR-6 & 0.10 & 0.125 & 0.01 & 18.0 & 30 & $-{ }^{*}$ \\
\hline DPR-1 & 0.05 & 0.05 & - & 35.0 & 40 & 67 \\
\hline DPR-2 & 0.05 & 0.055 & 0.01 & 34.5 & 40 & 60 \\
\hline DPR-3 & 0.05 & 0.060 & - & 34.0 & 45 & 57 \\
\hline DPR-4 & 0.05 & 0.063 & - & 34.0 & 45 & 85 \\
\hline DPR-5 & 0.05 & 0.100 & - & 30.0 & 45 & 66 \\
\hline DPR-6 & 0.05 & 0.100 & 0.01 & 30.0 & 45 & $-{ }^{*}$ \\
\hline DPR-7 & 0.05 & 0.151 & - & 25.0 & 50 & 63 \\
\hline DPR-8 & 0.05 & 0.200 & - & 20.0 & 50 & $-{ }^{*}$ \\
\hline
\end{tabular}

Note: ${ }^{*}$ - Obtained gellike substance is not applicable. 

(BR)

Synthesis of n-tert-buthylphenolformaldehyde

BR was synthesized by condensation of $n$-tertbuthylphenol with para-form at the molecular ratio of 1:1.3 in sour ambient [3]. The final product was brittle transparent yellow mass $\left(\mathrm{T}_{\mathrm{cr}}=91^{\circ} \mathrm{C}\right)$.

Synthesis of maleinized $n$-tert-buthylphenolformaldehyde (MBR)

A mixture of $16.2 \mathrm{~g}(0.1 \mathrm{~mol}$-equivalent $)$ of $\mathrm{n}$ tert-buthylphenolformaldehyde, $9.8 \mathrm{~g}(0.1 \mathrm{~mol})$ of maleic anhydride and $50 \mathrm{~mL}$ of ethyl-acetate was transformed into the three-necked reactor $(0.2 \mathrm{~L})$ which was equipped with a stirring rod, a backflow condenser and batch plant. The mass was heated until boiling, and then mixed for 1 hour. Backflow condenser was changed to direct flow one, when the solvent was distilled firstly at the atmospheric pressure then under water-jet vacuum up to $130^{\circ} \mathrm{C}$. The final product was brittle yellow transparent in thin layer substance, which is soluble in ethyl-acetate but carbohydrate-insoluble, $\mathrm{T}_{\mathrm{cr}}=112^{\circ} \mathrm{C}$. resin $(G B R)$

Synthesis of glycidated buthylphenolformaldehyde

A mixture of $6.7 \mathrm{~g}$ (0.041 mol-equivalent) of buthylphenolformaldehyde resin, $45 \mathrm{~mL}$ distilled water and $1.76 \mathrm{~g}(0.044 \mathrm{~mol})$ of $\mathrm{NaOH}$ was transformed into three-necked reactor $(0.1 \mathrm{~L})$ which was equipped with a stirring rod and backflow condenser. The mass was mixed at $55^{\circ} \mathrm{C}$ for 30 minutes up to solution creation where amorphous deposit was rejected at cooling, which then transformed into plastic mass. $3.7 \mathrm{~g}(0.040 \mathrm{~mol})$ of epichlorohydrin was added to the reaction mass and mixed at $30^{\circ} \mathrm{C}$ for 90 minutes. The next step was to add $20 \mathrm{~mL}$ of benzol and then to mix for $30 \mathrm{~min}$. After that, the mass was poured into a separating funnel. As soon as the phases were separated, the organic layer was extracted, rinsed by distilled water until getting neutral reaction according to phenolphtalein, and exposed to azeotropic dehydration by Dean-Stark trap. The solvent with the rest of epichlorohydrin was distilled, firstly at the atmospheric pressure then under water-jet vacuum up to $100^{\circ} \mathrm{C}$. The final product was greenishyellow transparent sticky mass. The content of epoxy groups was $5.9 \%$.

\section{IR spectroscopy}

IR spectra were collected by FT-IR analysis with the module Nicolet iZ10, adaptor Smart iTX ATR with the crystal Diamond and detector DTGS. Absorption bands ratio in spectra was conducted taking into account recommendations given elsewhere [11].

Calculations of Hildebrand solubility parameters and prediction of substances compatibility were conducted by Askadsky method [12].

Protective coatings tests were conducted according to the Ukraine technical conditions No. 00393707-002-95.

\section{Results and discussion}

The synthesis of modified phenolic resins based on maleinized n-tert-buthylphenol was conducted by the following scheme:
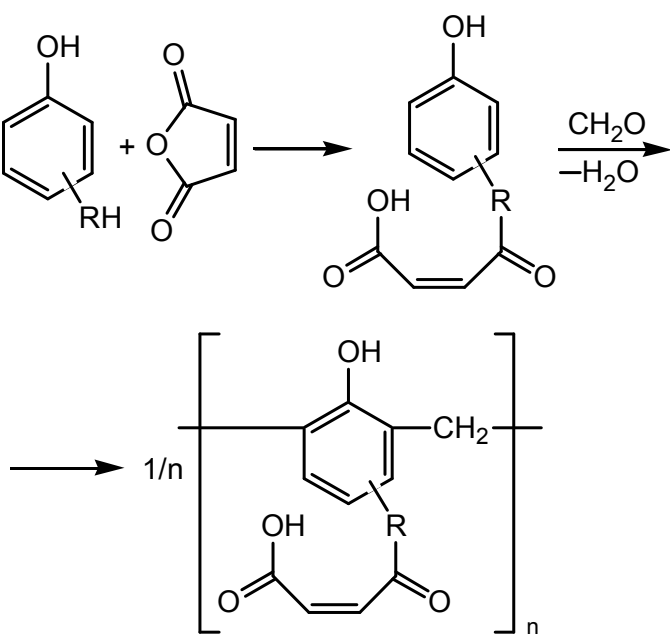

where $\mathrm{R}$ is meta- $\mathrm{O}-$; para- $\mathrm{C}_{\mathrm{C}}^{\mathrm{C}}$

Scheme 1. Synthesis of modified PR based on maleinized BR

Data given in Table 2 show the synthesis conditions and the main characteristics of modified phenolic resins at different ratios of adduct.

An increase in the amount of formaldehyde results in an increase in $\mathrm{T}_{\mathrm{cr}}$. Adduct acidity is sufficient for the catalysis of condensation by formaldehyde. It is important to note that the acid catalyst facilitates preparation of end product in case of a low amount of formaldehyde in the reaction mixture, whereas the catalyst introduction is unfavorable in case of an increased amount of formaldehyde, because a crosslinked product is obtained.

The above-mentioned processes and structures of adducts and modified phenolic resins have been confirmed by IR-spectral data. Specific absorption bands are shown in Table 3.

The spectra of PM and DM do not reveal absorption bands at 1854, 1782, 1242 and $1059 \mathrm{~cm}^{-1}$, which are typical of MA; this indicated the reaction behavior with the opening of anhydride ring. The 
Specific absorption bands in IR-spectra of modified phenolic resins, initial products and their adducts

\begin{tabular}{c|l}
\hline Compound & \multicolumn{1}{|c}{ Values of absorption bands, $\mathrm{cm}^{-1}$} \\
\hline MA & $1854 ; 1782 ; 1636 ; 1585 ; 1242 ; 1059 ; 896 ; 839 ; 696$ \\
\hline Resorcinol & $\begin{array}{l}3207 ; 3064 ; 3053 ; 3036 ; 1620 ; 1608 ; 1458 ; 1381 ; 1312 ; 1297 ; 1285 ; 1225 ; 1168 ; 1152 ; 1085 ; 998 ; \\
\\
963 ; 945 ; 930 ; 844 ; 773 ; 684\end{array}$ \\
\hline PM & $\begin{array}{l}3172 ; 3057 ; 1704 ; 1604 ; 1566 ; 1488 ; 1458 ; 1430 ; 1378 ; 1262 ; 1219 ; 1167 ; 1147 ; 961 ; 917 ; 861 ; 842 ; \\
772 ; 739 ; 679 ; 633 ; 608,593 ; 543\end{array}$ \\
\hline PPR & $\begin{array}{l}3247 ; 3058 ; 2959 ; 2936 ; 2872 ; 1702 ; 1616 ; 1508 ; 1443 ; 1411 ; 1378 ; 1212 ; 1162 ; 1083 ; 1020 ; 975 ; \\
842 ; 627 ; 591\end{array}$ \\
\hline DPA & $\begin{array}{l}3346 ; 3030 ; 2965 ; 2870 ; 1883 ; 1611 ; 1594 ; 1509 ; 1446 ; 1383 ; 1362 ; 1295 ; 1237 ; 1177 ; 1149 ; 1064 ; \\
1013 ; 827 ; 758 ; 552\end{array}$ \\
\hline DM & $\begin{array}{l}3181 ; 3057 ; 1703 ; 1605 ; 1488 ; 1459 ; 1429 ; 1376 ; 1295 ; 1219 ; 1166 ; 1145 ; 960 ; 862 ; 842 ; 771 ; 739 ; \\
679 ; 633 ; 611 ; 543\end{array}$ \\
\hline DPR & $\begin{array}{l}3256 ; 3049 ; 2964 ; 2936 ; 2868 ; 1704 ; 1609 ; 1501 ; 1423 ; 1361 ; 1224 ; 1176 ; 1147,1115 ; 1040 ; 1013 ; \\
\\
882 ; 819 ; 553\end{array}$ \\
\hline
\end{tabular}

presence of absorption bands at 2936 and 2872$2868 \mathrm{~cm}^{-1}$ in the spectra of PPR and DPR corresponds to valent and bending vibrations of $\mathrm{C}-\mathrm{H}$ in methylene group. Intensive absorption bands at 2964-2959 $\mathrm{cm}^{-1}$ in the spectra of PPR and DPR can be associated with asymmetrical valent bending vibrations in $-\mathrm{CH}_{3}$ groups, which were introduced as a result of butanolisis when synthesized. The spectra of PM, DM, PPR and DPR demonstrate the bands at $3049-2058 \mathrm{~cm}^{-1}$, which are typical of asymmetrical valent vibrations of $\mathrm{C}-\mathrm{H}$ in alkenes, and the intensive bands at $1704-1702 \mathrm{~cm}^{-1}$, which show valent vibrations of $\mathrm{C}=\mathrm{O}$ in the group $>\mathrm{C}=\mathrm{C}-\mathrm{COOH}$. In addition, the bands at 1604$1616 \mathrm{~cm}^{-1}$ are observed, which correspond to valent vibrations $>\mathrm{C}=\mathrm{C}<$ in the presence of conjugation with $\mathrm{C}=\mathrm{O}$ group.

The band at $1704.9 \mathrm{~cm}^{-1}$ is present in the spectrum of MBR (Figure), which corresponds to valent vibration of $\mathrm{C}=\mathrm{O}$ group in $\alpha, \beta$-unsaturated acids. The band at $1218.3 \mathrm{~cm}^{-1}$ may be due to vibrations of $\mathrm{C}-\mathrm{O}-\mathrm{C}$ in esters. The band at $1134.3 \mathrm{~cm}^{-1}, 1108.4 \mathrm{~cm}^{-1}$ and $1039.1 \mathrm{~cm}^{-1}$ in the spectrum of GBR corresponds to valent vibrations of $\mathrm{C}-\mathrm{O}-\mathrm{C}$ in cyclic and linear ethers.

Systems based on modified phenolic resins with vegetable oil and their derived products are efficient protective coatings. For instance, these are the compositions synthesized by combining of phenolic resins, epoxide resins, vegetable oil, mainly tung-oil (TO) [4]. To understand the application of the synthesized phenolic resins as the components of film-forming systems, they were tested in model compositions that include vegetable oil or they derived products. Composition content was identified by the results of prospective compatibility of phenolic resins with other ingredients of protective

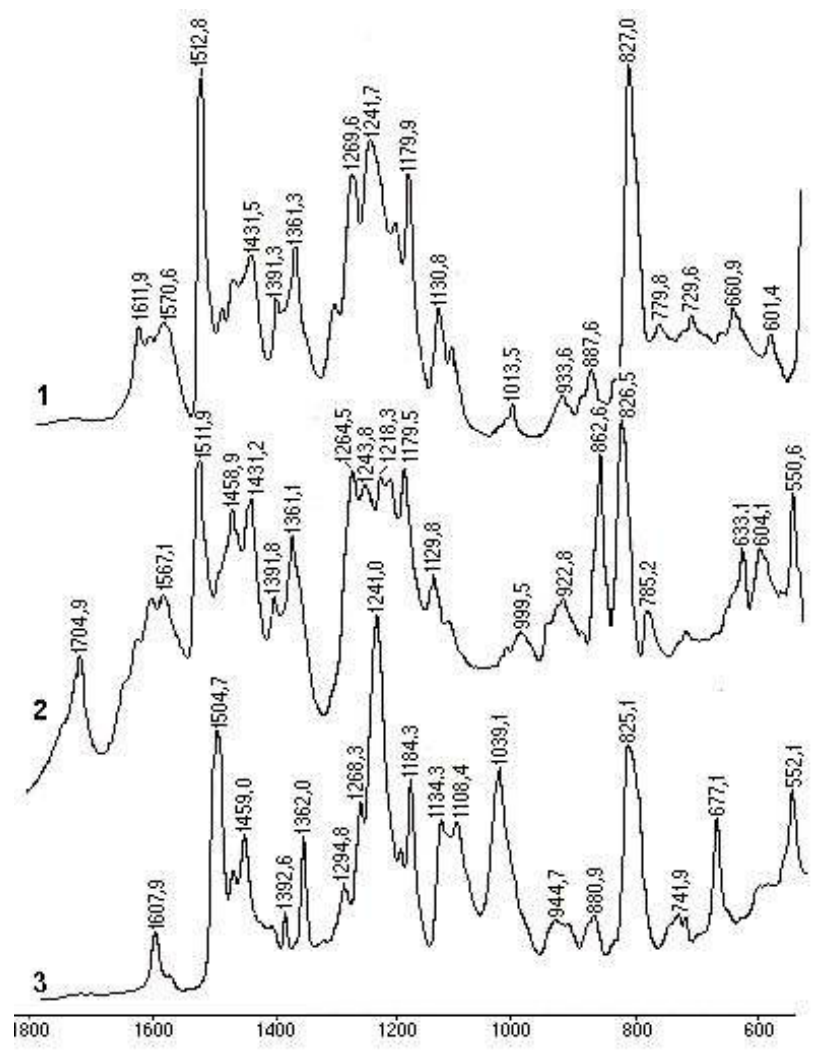

IR-spectra of BP (1), MBR (2) and GBR (3)

compositions by comparison of Hildebrand solubility parameter that was calculated by the following equation developed by Askadsky [12]:

$\delta=\left(\frac{\sum_{i} \Delta E_{i}^{*}}{N_{A} \sum_{i} \Delta V_{i}}\right)^{0.5}$, 
where $\delta$ is the Hildebrand solubility parameter $\left(J^{0.5} \mathrm{~m}^{-1.5}\right) ; \Delta \mathrm{E}_{\mathrm{i}}^{*}$ is the contribution of the $\mathrm{i}$-th atom or the type of intermolecular interaction to the value of the cohesion energy of matter $\left(\mathrm{J} \mathrm{mol}^{-1} ; \mathrm{N}_{\mathrm{A}}\right.$ is the Avogadro constant $\left(\mathrm{mol}^{-1}\right) ; \Delta \mathrm{V}_{\mathrm{i}}$ is the increment of the Van-Der-Waals volume of the $\mathrm{i}$-th atom of matter $\left(\AA^{3}\right)$.

The results of calculation performed by using formula (1) are given in Table 4.

Table 4

\section{Characteristics of synthesized $P R$ and vegetable oil}

\begin{tabular}{c|c|c|c}
\hline Compound & $\Sigma \Delta \mathrm{E}_{\mathrm{i}}{ }^{*}, \mathrm{~J} \mathrm{~mol}^{-1}$ & $\Sigma \Delta \mathrm{V}_{\mathrm{i}}, \AA^{3}$ & $\delta, \mathrm{J}^{0.5} \mathrm{~m}^{-1.5}$ \\
\hline BR & 9598.5 & 175.6 & 19.5 \\
\hline MBR & 17553.5 & 252.7 & 22.0 \\
\hline GBR & 14014.0 & 226.4 & 20.7 \\
\hline PPR' $^{\prime}$ & 14717.3 & 182.9 & 23.7 \\
\hline DPR $^{\prime}$ & 22486.6 & 309.4 & 22.5 \\
\hline PPR & 13372.7 & 237.4 & 19.8 \\
\hline DPR & 18939.2 & 380.1 & 18.6 \\
\hline ER $^{1}$ & 25101.6 & 380.1 & 21.4 \\
\hline EO $^{2}$ & 54540.2 & 987.5 & 19.6 \\
\hline TO & 41161.6 & 991.0 & 17.0 \\
\hline
\end{tabular}

Notes: ${ }^{1}$ - Epikote-828 is an epoxydiane resin based on BPA produced by HEXION, analogue of ED-22; ${ }^{2}-$ ArStab-1701 is an epoxydiane soybean oil produced by «Arsenal-group» Ltd., UTD 24.1-32926424-001:2012.

According to the available data $[13,14]$, thermodynamic compatibility of substance and solvent is feasible if the following condition is fulfilled:

$\left|\delta_{1}-\delta_{2}\right| \leq(3.07 \div 4.09) \cdot \mathrm{MJ}^{0.5} \cdot \mathrm{m}^{-1.5}$

where $\delta_{1}$ and $\delta_{2}$ are the solubility parameters concerning the solvent and the substance, respectively
$\left(\mathrm{MJ}^{0.5} \mathrm{~m}^{-1.5}\right)$.

If $\mathrm{TO}$ or $\mathrm{EO}$ is considered as a solvent, then according to the calculation results, the rest of above mentioned substances are supposed to change the solubility in the following sequence (the value of $\left|\delta_{1}-\delta_{2}\right|$ is given here in brackets):

$$
\text { - for TO: }
$$

$\operatorname{DPR}(1.6)>\mathrm{BR}(2.5)>\mathrm{EO}(2.6)>\operatorname{PPR}(2.8)>\mathrm{GBR}(3.8)>$ $>\operatorname{ER}(4.4)>>\operatorname{MBR}(5.0)>\mathrm{DPR}^{\prime}(5.5)>\mathrm{PPR}^{\prime}(6.7)$;

$$
\text { - for EO: }
$$

$\operatorname{BR}(0.1)>\operatorname{PPR}(0.2)>\operatorname{GBR}(1.1)>\mathrm{EC}(1.8)>$ $>\operatorname{MBR}(2.4)>\mathrm{TO}(2.6) \mathrm{DPR}^{\prime}(2.9)>>\mathrm{PPR}^{\prime}(4.1)$.

According to the above-mentioned data, TO is likely to be compatible with synthesized phenolic resins, such as DPR, BR, PPR and GBR as well as epoxy-containing substances; whereas EO is likely to be compatible with all investigated substances phenolic resins except for PPR'.

Similar calculations were performed for the system organic solvent - phenolic resins, oil and epoxy-containing substances to predict the choice of the solvents suitable to make stable solutions with the synthesized substances. The data about the chosen organic solvents and the results of calculation are listed in Table 5.

It is seen from Table 5 that carbohydrate aromatic and aliphatic solvents can make thermodynamically compatible systems with oils, ER, $\mathrm{BR}$, and butanolized products of condensation of adducts of bisphenol-maleic anhydride with formaldehyde. Moreover, there are some suitable solvents for indicated substances such as tetrahydrofuran, ethyl acetate, acetone and dioxane.

Data about predicted compatibility of organic solvents and PR, oil and epoxy-containing substances

\begin{tabular}{l|c|c|c|c|c|c|c|c|c|c|c}
\hline \multirow{2}{*}{ Solvent } & \multirow{2}{*}{$\delta_{1}}$, & \multicolumn{10}{|c}{$\left|\delta_{1}-\delta_{2}\right|$, for substances } \\
\cline { 3 - 13 } & & BR & MBR & GBR & PPR' & DPR' & PPR & DPR & Epikote-828 & ArStab-1701 & TO \\
\hline WS & 17.7 & 1.8 & 4.3 & 3.0 & 6.0 & 4.8 & 2.1 & 0.9 & 3.7 & 1.9 & 0.7 \\
\hline Toluene & 18.2 & 1.3 & 3.8 & 2.5 & 5.5 & 4.3 & 1.6 & 0.4 & 3.2 & 1.4 & 1.2 \\
\hline TGF & 18.5 & 1 & 3.5 & 2.2 & 5.2 & 4.0 & 1.3 & 0.1 & 2.9 & 1.1 & 1.5 \\
\hline EA & 18.6 & 0.9 & 3.4 & 2.1 & 5.1 & 3.9 & 1.2 & 0.0 & 2.8 & 1 & 1.6 \\
\hline Acetone & 20.0 & 0.5 & 2.0 & 0.7 & 3.7 & 2.5 & 0.2 & 1.4 & 1.4 & 0.4 & 3.0 \\
\hline Dioxane & 20.2 & 0.7 & 1.8 & 0.5 & 3.5 & 2.3 & 0.4 & 1.6 & 1.2 & 0.6 & 3.2 \\
\hline NB & 23.3 & 3.8 & 1.3 & 2.6 & 0.4 & 0.8 & 3.5 & 4.7 & 1.9 & 3.7 & 6.3 \\
\hline IPA & 24.0 & 4.5 & 2.0 & 3.3 & 0.3 & 1.5 & 4.2 & 5.4 & 2.6 & 4.4 & 7.0 \\
\hline Ethanol & 26.0 & 6.5 & 4.0 & 5.3 & 2.3 & 3.5 & 6.2 & 7.4 & 4.6 & 6.4 & 9.0 \\
\hline Methanol & 29.6 & 10.1 & 7.6 & 8.9 & 5.9 & 7.1 & 9.8 & 11.0 & 8.2 & 10.0 & 12.6 \\
\hline
\end{tabular}

Note: * WS - white spirit; TGF - tetrahydrofuran; EA - ethyl acetate; NB - n-butyl alcohol; and IPA - isopropyl alcohol. 
As for PPR' and DPR', which were not processed by butyl alcohol, they are compatible with solvents with $\delta_{1}$ of 20 to $26 \mathrm{MJ}^{0.5} \mathrm{~m}^{-1.5}$. The highest efficiency with respect to the solubility of investigated mixtures of phenolic resins, oils and epoxy-containing substances are expected to be the solvents with $\delta_{1}$ of 19.7 to $21.0 \mathrm{MJ}^{0.5} \mathrm{~m}^{-1.5}$. Liquids with these parameters can be prepared by the addition of individual solvents in a certain ratio. In this case, the value $\delta_{\mathrm{ij}}$ is calculated by the following formula:

$\delta_{\mathrm{ij}}=\frac{\mathrm{X}_{\mathrm{i}} \mathrm{V}_{\mathrm{i}} \delta_{\mathrm{i}}{ }^{+} \mathrm{X}_{\mathrm{j}} \mathrm{V}_{\mathrm{j}} \delta_{\mathrm{j}}}{\mathrm{X}_{\mathrm{i}} \mathrm{V}_{\mathrm{i}}+\mathrm{X}_{\mathrm{j}} \mathrm{V}_{\mathrm{j}}}$

where $\delta_{\mathrm{ij}}$ is the solubility parameter of the solvents mixture; $\mathrm{x}_{\mathrm{i}(\mathrm{j})}, \mathrm{V}_{\mathrm{i}(\mathrm{j})}$, and $\delta_{\mathrm{i}(\mathrm{j})}$ are the mole fractions, mole volumes $\left(\mathrm{cm}^{3} \mathrm{~mol}^{-1}\right)$ and solubility parameters $\left(\mathrm{MJ}^{0.5} \mathrm{~m}^{-1.5}\right)$; the subscripts $\mathrm{i}$ and $\mathrm{j}$ are related to the individual different solvents.

It is interesting to note that indicated range of $\mathrm{X}_{\mathrm{ij}}$ is obtained by the mixture of ethyl acetate and other mentioned solvents providing that the mole fractions in a mixture is as follows: acetone: from 1.0 to 0.8 ; dioxane: from 1.0 to 0.7 ; n-butyl alcohol and isopropyl alcohols: from 0.5 to 0.3 ; and ethanol and methanol: from 0.4 to 0.3 .

The experimental tests showed that the conclusions about the compatibility of phenolic resins with oils and organic solvents with synthesized phenolic resins are valid. The composition and characteristics of homophasic transparent mixtures are shown in Table 6.

Stable compositions based on thermodynamically incompatible TO and MBR are prepared by preliminary thermostating of their mixtures of TO-phenolic resin at increased temperature. Plausible reason for the formation of a homophasic system is a compatibilization effect resulted from the Diels-Alder reaction between fragments of conjugated non-saturated groups in remains of elaeostearic acid in TO and non-saturated group of the maleic group according to the following scheme 2.

The composition based on basic recipe of means of sophisation R 101, where ingredients Epikote828 and BR SMD 31144 were substituted by equivalent amount of synthesized GBR, was tested. According to results of the tests, the obtained coatings satisfy all technical rules and regulations.

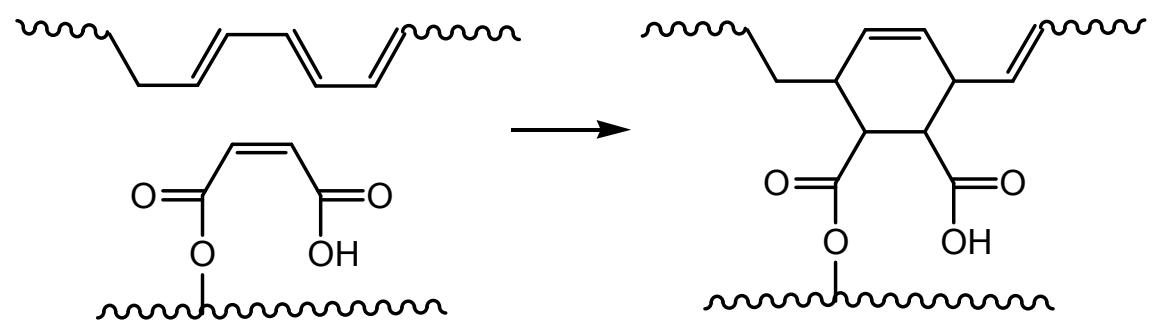

Scheme 2. Diels-Alder reaction

Table 6

Composition and characteristics of model compositions

\begin{tabular}{|c|c|c|c|c|c|c|c|c|c|c|c|c|c|c|}
\hline \multirow{3}{*}{ No. } & \multicolumn{8}{|c|}{ Content of components, wt. $\%$} & \multicolumn{2}{|c|}{$\begin{array}{c}\text { Drying } \\
\text { duration, } \mathrm{h}\end{array}$} & \multicolumn{4}{|c|}{ Properties of coating } \\
\hline & \multirow{2}{*}{ MBR } & \multirow{2}{*}{ PPR } & \multirow{2}{*}{ DPR } & \multirow{2}{*}{ TO } & \multirow{2}{*}{ EO } & \multirow{2}{*}{ WS } & \multirow{2}{*}{ EA } & \multirow{2}{*}{ NB } & \multirow{2}{*}{$20^{0} \mathrm{C}$} & \multirow{2}{*}{$110^{\circ} \mathrm{C}$} & \multirow{2}{*}{$\begin{array}{c}\text { adhesion, } \\
\text { points }\end{array}$} & \multirow{2}{*}{$\begin{array}{c}\text { Elasticity, } \\
\mathrm{mm}\end{array}$} & \multicolumn{2}{|c|}{ Resistance to environments $^{3}$} \\
\hline & & & & & & & & & & & & & seawater & mineral oil \\
\hline 1 & 50 & & & & & & 50 & & 4 & 8 & 4 & 4 & n.p. & n.p. \\
\hline 2 & 25 & & & 25 & & & 50 & & 3 & 3 & 2 & 4 & p. & $\mathrm{p}$ \\
\hline $3^{1}$ & 20 & & & 20 & 10 & & 50 & & 3 & 3 & 1 & 2 & $\mathrm{p}$. & $\mathrm{p}$. \\
\hline $4^{2}$ & 20 & & & 20 & 10 & & 50 & & 3 & - & 1 & 1 & p. & p. \\
\hline 5 & & 17 & & & 6 & & 77 & & 4 & 3 & 3 & 3 & n.p. & p. \\
\hline 6 & & 17 & & & 6 & 10 & 67 & & 4 & 3 & 2 & 3 & $\mathrm{p}$ & p. \\
\hline 7 & & & 37 & & 5 & & 58 & & 4 & 2 & 3 & 2 & p. & p. \\
\hline 8 & & & 37 & & 5 & & & 58 & 4 & 3 & 2 & 1 & p. & p. \\
\hline 9 & & & 37 & & 5 & & 34 & 24 & 4 & 3 & 1 & 2 & p. & p. \\
\hline 10 & & & 36 & & 7 & & 34 & 23 & 4 & 3 & 1 & 1 & p. & n.p. \\
\hline
\end{tabular}

Notes: ${ }^{1}-$ explanation is given in the main text; ${ }^{2}-$ the composition contained $0.3 \%$ of desiccant and a mixture of Co, Mn and $\mathrm{Zn}$ naphthenates; ${ }^{3}-\ll n . p . »$ means that the coating has not passed the test, «p.» means that the coating has passed the test. 


\section{Conclusions}

Modified phenolic resins, prepared by monoesterification of bisphenols by maleic anhydrite and further condensation with formaldehyde as well as esterification by maleic anhydrite or glycidation of phenol-formaldehyde resins by epichlorohydrin, can be suggested as components of protective coatings in a combination of drying oils and epoxidated oils. Development of compositions for protective coatings is efficient to be done taking into account Hildebrand solubility parameters of filmmaking components and solvents.

\section{REFERENCES}

1. Pilato L. Phenolic resins: 100 Years and still going strong // React. Funct. Polym. - 2013. - Vol.73. - No. 2. - P.270277.

2. Gardziella A., Pilato L., Knop A. Phenolic resins: chemistry, application, standardization, safety and ecology. Germany: Springer-Verlag Berlin Heidelberg, 2000. - 584 p.

3. Варлан К.С., Северенчук І.М., Зубенко А.М. Маловідходний процес отримання бутилфенолформальдегідної смоли для захисних покрить // Вісник Дніпровського ун-ту. Серія Хімія. - 2017. - Т.25. - № 2. - С.58-64.

4. Северенчук М.В., Тренін М.Ф., Кожина Ю.В. Пат. 50150 Україна, МПК С 09 D 5/08, С 09 D 5/10, С 09 D 161/00. Композиція для захисного покриття R-101. - № 2011107201; Заявл. 23.10.2001; Опубл. 15.02.2002. Бюл. № 10. -5 c.

5. Biedermann M., Grob K. Phenolic resins for can coatings: I. Phenol-based resole analysed by GC-MS, GC $\times$ GC, NPLC - GC and SEC // LWT Food Sci. Technol. - 2006. - Vol.39. - No. 6. - P. 633-646.

6. Krasinskyi V., Spisak E., Gajdos I., Garbacz T. Heatresistant coatings on the basis of phenol-formaldehyde compositions // Mater. Sci. Forum. - 2015. - Vol.818. P. 105-108.

7. Motawie A.M., Sadek E.M. Adhesives and coatings based on phenolic/epoxy resins // Polym. Adv. Technol. - 1999. Vol.10. - P. 223-228.

8. Прохоров П.В., Тузова С.Ю. Модифицированные эпоксидно-фенольные композиции // Успехи в химии и хим. технологии. - 2012. - Т.26. - № 4. - С.73-77.

9. Тузова С.Ю., Антипов Е.М. Пат 2502757 РФ, МПК С 08 L 63/02, С 08 L 61/06, С 08 L 5/54. Эпоксидно-фенольная композиция. - № 2011145282/05; Заявл. 09.11.2011; Опубл. 27.12.2013. - Бюл. № 14. - 6 с.
10. Suvorova Yu., Chervakov O. Synthesis, properties and application of butanolic ethers of condensation products of diphenylolpropane and formaldehyde // Матеріали III Міжн. конф. молодих вчених ССТ-2013, 21-23 листопада 2013 р. Україна, Львів. - С.60-61.

11. Тарасевич Б.Н. ИК спектры основных классов органических соединений. Справочные материалы. - М.: МГУ, 2012. $-54 \mathrm{c}$.

12. Аскадский А.А., Кондращенко В.И. Компьютерное материаловедение полимеров. - Т.1. - Атомно-молекулярный уровень. - М.: Научный мир, 1999. - 544 с.

13. Дринберг С.А., Иико Э.Ф. Растворители для лакокрасочных материалов. - Л.: Химия, 1986. - 208 с.

14. Геллер Б.Э., Геллер А.А., Чиртулов В.Г. Практическое руководство по физикохимии волокнообразующих полимеров. - М.: Химия, 1996. - 432 с.

Received 04.09.2019

\section{МОДИФІКОВАНІ ФЕНОЛЬНІ СМОЛИ ТА ЇХ СУМІСНІСТЬ 3 КОМПОНЕНТАМИ ЕПОКСИ- ФЕНОЛЬНИХ ЗАХИСНИХ ПОКРИТТІВ}

\section{К.Є. Варлан, Д.О. Черваков, О.С. Свердліковська,} С.С. Загинайко, І.М. Северенчук

Для одержання перспективних плівкоутворювальних систем синтезовані продукти конденсації моноестерифікованих малеїновим ангідридом резориину, дифенілолпропану з формальдегідом, продукти малеїнування та гліцидування бутилфенолформальдегідної смоли. Наведено методики синтезів, характеристики синтезованих фенольних смол і результати IЧспектрального аналізу проміжних та кінцевих продуктів. Складання рецептур модельних плівкоутворювальних систем на основі синтезованих смол здійснювали шляхом прогнозування їх термодинамічної сумісності з іншими компонентами (оліями, розчинниками) за допомогою параметрів розчинності Гільдебранда, розрахованих за методом Аскадського. Експериментальна перевірка показала відповідність отриманих і прогнозованих результатів щодо сумісності синтезованих смол з тунговою та епоксидованою соєвою оліями і розчинниками. Синтезовані сполуки можуть розглядатися як компоненти захисних покриттів в комбінації з висихаючими та епоксидованими оліями.

Ключові слова: малеїновий ангідрид, резорцин, дифенілолпропан, модифікована фенольна смола, параметр розчинності, захисне покриття. 


\section{MODIFIED PHENOLIC RESINS AND THEIR COMPATIBILITY WITH THE COMPONENTS OF EPOXY- PHENOLIC PROTECTIVE COATINGS}

\author{
K.E. Varlan ${ }^{a,}$, D.O. Chervakov ${ }^{b}$, O.S. Sverdlikovska ${ }^{b}$, \\ E.C. Zahinayko ${ }^{c}$, I.M. Severenchuk ${ }^{a}$
}

a Oles Honchar Dnipro National University, Dnipro, Ukraine b Ukrainian State University of Chemical Technology, Dnipro, Ukraine

c Dnipropetrovsk Forensic Research Center of the Ministry of Internal Affairs of Ukraine, Dnipro, Ukraine

\section{* e-mail: konstvarlan@meta.ua}

Condensation products of resorcinol mono-esterified by maleic anhydride, diphenylpropane with formaldehyde, products of maleinization and glycidation by butylphenol formaldehyde resins were synthesized. The obtained products can be used in film-forming systems. The methods of the synthesis were developed; the characteristics of the synthesized phenolic resins and the results of the IR-spectral analysis of intermediates and end products were given. Formulation of the model film-forming systems based on the synthesized resins was performed by predicting their thermodynamic compatibility with other components (oils and solvents) using Hildebrand parameters, the solubility being calculated by the Askadsky method. Experimental verification showed that the obtained results complied with the predictions on the compatibility of the synthesized resins with tung and epoxidized soy oils and solvents. The synthesized compounds can be considered promising components for protective coatings in combination with drying and epoxidized oils.

Keywords: maleic anhydride; resorcinol; diphenylolpropane; modified phenolic resin; solubility parameter; protective coating.

\section{REFERENCES}

1. Pilato L. Phenolic resins: 100 years and still going strong. Reactive and Functional Polymers, 2013, vol. 73, no. 2, pp. 270277.

2. Gardziella A., Pilato L., Knop A., Phenolic resins: chemistry, application, standardization, safety and ecology. SpringerVerlag, Berlin, Heidelberg, 2000. 584 p.

3. Varlan K.E., Severenchuk I.M., Zubenko A.M. Malovidkhodnyi protses otrymannya butylfenolformal'dehidnoyi smoly dl'ya zakhysnykh pokryt' [Low-waste process for producing butylphenol-formaldehyde resin for protective coatings]. Visnyk Dniprovs'kogo Universytetu. Seriya Khimiya, 2017, vol. 25, no. 2, pp. 58-64. (in Ukrainian).

4. Severchuk M.V., Trenin M.F., Kozhina Yu.V., Kompozytsiya dl'ya zakhysnogo pokryttya $R$-101 [Composition for protective coating R-101]. Patent UA, no. 50150, 2002. (in Ukrainian).
5. Biedermann M., Grob K. Phenolic resins for can coatings: I. Phenol-based resole analysed by $\mathrm{GC}-\mathrm{MS}, \mathrm{GC} \times \mathrm{GC}$, NPLC-GC and SEC. LWT - Food Science and Technology, 2006, vol. 39, pp. 633-646.

6. Krasinskyi V., Spisak E., Gajdos I., Garbacz T. Heatresistant coatings on the basis of phenol-formaldehyde compositions. Materials Science Forum, 2015, vol. 818, pp. 105108.

7. Motawie A.M., Sadek E.M. Adhesives and coatings based on phenolic/epoxy resins. Polymers for Advanced Technologies, 1999, vol. 10, pp. 223-228.

8. Prokhorov P.V., Tuzova S.Yu. Modifitsirovannyye epoksidno-fenol'nyye kompozitsii [Modified epoxy phenolic compositions]. Uspekhi v Khimii i Khimicheskoi Tekhnologii, 2012, vol. 26, no. 4, pp. 73-77. (in Russian).

9. Tuzova S.Yu., Antipov E.M., Epoksidno-fenol'naya kompozitsiya [Epoxy-phenolic composition]. Patent RF, no. 2502757, 2013. (in Russian).

10. Suvorova Yu., Chervakov O., Synthesis, properties and application of butanolic ethers of condensation products of diphenylolpropane and formaldehyde. Proceedings of the III International Conference «Chemistry \& Chemical Technology 2013» (CCT-2013). Ukraine, Lviv, 2013, pp. 60-61.

11. Tarasevich B.N., IK spektry osnovnykh klassov organicheskikh soyedinenii. Spravochnye materialy [IR spectra of the main classes of organic compounds: a reference book]. Moscow State University Publishers, Moscow, 2012. 54 p. (in Russian).

12. Askadsky A.A., Kondrashchenko V.I., Komp'yuternoe materialovedenie polimerov. Atomno-molekulyarnyi uroven' [Computer materials science of polymers: atomic-molecular level]. Scientific World Publishers, Moscow, 1999. 544 p. (in Russian).

13. Drinberg S.A., Itsko E.F., Rastvoriteli dl'ya lakokrasochnykh materialov [Solvents for paints and varnishes]. Khimiya, Leningrad, 1986. 208 p. (in Russian).

14. Geller B.E., Geller A.A., Chirtulov V.G., Prakticheskoe rukovodstvo po fizikokhimii voloknoobrazuyushchikh polimerov [A practical guide on the physical chemistry of fiber-forming polymers]. Khimiya, Moscow, 1996. 432 p. (in Russian). 